\title{
A PROVA NO “DESVIO DE PODER"
}

J. CRETElla JúNioR*

O "desvio de poder", ou seja, o uso do poder discricionário pelo administrador para atingir fins privados, divorciados do interesse público, ocorre quando a má fé ou qualquer sentimento pessoal informa a edição do ato.

Nesses casos, o administrador procede com extrema cautela, escondendo o verdadeiro motivo da medida tomada e mascarando sua iniciativa ilegal com a aparência de medida que atenda ao interesse público.

Daí, a dificuldade em apurar a "prova do desvio", quando o prejudicado pelo ato pretende recorrer ao Poder Judiciário.

Entretanto, por mais cauteloso que seja, o administrador, acaba ele revelando seu deslize, o "animus nocendi", prejudicando o funcionário, ou então, favorecendo o amigo.

Em 18 de março de 1940, o Tribunal de Justiça de Pernambuco decidiu ser nulo um decreto expropriatório, que não se fundamentara no interesse público, mas em objetivos privados, erigindo-se o acórdão como o nosso leading case, em matéria de "desvio de poder", pois o Chefe do Executivo Municipal, de convicção católica, procurou desapropriar um templo protestante, inspirando-se o decreto em móvel ou motivo religioso e não no interesse público.

Fácil, pois, é compreender que quando o administrador usa o poder discricionário de que é detentor para fins privados, prejudicando ou beneficiando o administrado, não será tão ingênuo que vá confessá-lo ou deixar vestígios palpáveis de sua conduta irregular.

Nesses casos, o administrador disfarça o motivo verdadeiro que o inspirou, na prática do ato, apresentando oficialmente um pretexto legal.

$\mathrm{Na}$ doutrina, o trabalho pioneiro sobre o tema foi escrito em 1951 por CAIO TÁCITO, com sua notável tese Desvio de poder, em matéria administrativa, edição mimeografada, fora do comércio, posteriormente inserida no livro Direito Administrativo, S. Paulo, 1975, edição Saraiva, páginas 43 a 133, tese que nos inspirou na

* Advogado em São Paulo.

R. Dir. Adm.,

Rio de Janeiro, 230: 197-216,

Out./Dez. 2002 
feitura de nossa monografia Do desvio de poder, tese com que, em 1965, obtivemos a livre-docência de Direito Administrativo na Faculdade de Direito da Universidade de São Paulo.

Mais tarde, alguns processualistas, como TEOTÔNIO NEGRÃO, disseram-me que o estudo da prova ainda não fora feito e, assim, procuramos, na literatura universal e pátria, exemplos indiscutíveis de condutas do administrador que lhe revelassem o animus, ou seja, dirigimos nossa atenção para o tema da prova no desvio de poder.

A prova do desvio de poder deverá consistir em algo palpável, concreto, fato que se projete no mundo jurídico, criando a certeza da conduta ilegal e fornecendo, desse modo. fato concreto para o julgador formar sua conviç̧ão sobre a patologia do ato e prolatar sentença, anulando-o.

No caso, a prova, regra geral, é difícil. Assim como os sintomas denunciadores de moléstia insidiosa resistem aos esforços do especialista para fazer o diagnóstico que revele a causa do mal, a prova do desvio de poder desafia também a argúcia do intérprete que pretende surpreender o animus do administrador, mascarando-se essa conduta de maneira sutil e escapando, não raro, à apreensão objetiva.

A seguir apresentaremos as mais evidentes condutas ou deslizes, provas que permitem identificar o ato administrativo editado com desvio de poder: a) contradição do ato com conduta posterior do administrador; b) contradição do ato com conduta anterior; c) motivação contraditória; d) motivação insuficiente; e) alteração dos fatos; e) ilogicidade manifesta; f) injustiça patente; g) disparidade de tratamento; h) derrogação de norma interna; i) precipitação com que o ato foi editado; j) inexistência, de fato, dos motivos apresentados pelo administrador para justificar a decisão tomada; 1) desigualdade de tratamento dispensada aos interessados; $m$ ) caráter sistemático de certas proibições; $n$ ) caráter geral atribuído a medida que deveria permanecer particular; o) circunstâncias locais que antecederam a edição do ato; p) feixe convergente de indícios.

A prova do ato jurídico, indispensável para tornar válidas as relações de direito, quando contestadas, pode ser definida como a soma dos meios, ou seja, a série ou conjunto dos fatos probatórios produtores da certeza, isto é, capazes de afirmar o fato 'probando' e, portanto, criadores da evidência. É tudo que nos pode convencer da certeza de algum fato, circunstância ou proposição controvertida. As provas, portanto, são os elementos que determinam a convicção do juiz.

Os atos administrativos presumem-se válidos. O onus da prova incumbe a quem alega os fatos. Por isso, qualquer vício deve ser provado por quem o invoca, estando incluído, nessa hipótese, o desvio de poder.

Compreendem-se, por aí, as dificuldades com que se vai defrontar o administrado, em razão de sua natural posição de inferioridade perante a Administração.

Tem de provar-se que se deram certos fatos, em conexão com a prática do ato administrativo, que esses fatos demonstram que os fins visados pelo exercício do poder discricionário não foram os fixados na lei, que tais fins agiram, como motivo de resolução, no espírito dos indivíduos, suporte dos órgãos que o editaram e foram exclusivamente determinantes do ato praticado.

À prova do desvio de poder não interessam os manejos de pessoas diferentes das autoridades ou dos membros dos colegiados autores do ato, nem importa a 
“opinião pública”, a "voz corrente", não concretizada em fatos típicos, demonstrativos do caráter determinante dos motivos alegados.

Embora manifestamente só interesse conhecer os motivos de quem decidiu ou deliberou, parece-nos todavia que a prova do dolo ou da má fé de terceiros, quando esse dolo ou má fé tenham sido determinantes da conduta da Administração, constitui elemento não despiciendo de apreciação que poderá ajudar a demonstrar quais os verdadeiros motivos do ato.

A prova do desvio de poder deve encontrar-se na documentação que figura no expediente administrativo ou que se incorpora desde logo ao expediente jurídico. Também se admite a prova testemunhal, assim como a prova indiciária, mas apreciando-as com critério restritivo e exigindo que as presunções sejam graves, concordes e precisas.

Efetivamente, este aspecto de contraste da legalidade do ato obriga, da parte do julgador, exame aprofundado, em matéria de prova: não se trata aqui de elementos externos, como a forma e a competência, nem se trata também de elementos internos relativos ao objeto do ato, que precisam passar pelo crivo da crítica: é a psicologia do autor do ato que vai ser examinada e apreciada pelo juiz. Isto explica porque o desvio de poder, no direito francês, aparece mais tarde que outros motivos para a interposição do recurso por excesso de poder, assinalando com sua presença a amplitude do exame jurisdicional.

No exame da prova, convém tomar precauções, pois seria erro pensar que a Administração examina a internação subjetiva, o "processus" interno da vontade do agente. Ele não perscruta seus rins e coração: é ao próprio ato e aos documentos administrativos que o acompanham que se pede a prova do desvio de poder. É o arquivo, o fichário que deve fornecer tal convicção ou qualquer outra prova: uma carta, um bilhete, uma confissão, uma prova indireta, um artigo de jornal, uma entrevista.

Fácil é compreender que quando o administrador usa os poderes de que é detentor para fim nefando, não será ingênuo em confessá-lo ou em deixar vestígios palpáveis de sua conduta. Disfarça, então, os motivos verdadeiros do ato praticado e apresenta, oficialmente, um pretexto legal. Trata-se de desmascarar o embuste, o que nem sempre é fácil. Na França, o Conselho de Estado, neste particular, está mais bem aparelhado para descobrir a verdade do que os tribunais judiciários (Marcel Waline, Traité élémentaire de droit administratif, $6^{\mathrm{a}}$ ed., 1952, p. 144).

No início, o Conselho de Estado francês mostra-se excessivamente tímido, chegando certa vez a declarar que não lhe competia investigar os motivos das decisões tomadas pelos "maires", pelos "prefeitos".

Assim, só toma a iniciativa de anular decisão municipal, acoimada de desvio de poder, quando se apoia em prova irrefutável, qual seja, os próprios termos de uma carta do "maire" notificando a suspensão, da qual se depreende que agiu com finalidade diversa daquela que reclamavam os interesses que lhe foram confiados.

A partir dessa ocasião, o Conselho de Estado se torna mais audacioso.

$\mathrm{Na}$ realidade, seria facílimo para o administrador pouco escrupuloso tomar decisões inspiradas em móveis estranhos ao interesse público, se lhe bastassem, para fugir à censura, os verdadeiros motivos de seu ato, quer no próprio texto deste, quer 
na carta de notificação (Marcel Waline, Traité élémentaire de droit administratif, $6^{\mathrm{a}}$ ed., 1962, p. 1440).

Por outro lado, as medidas administrativas precisam ser resguardadas de abusos que a qualquer pretexto poderiam verificar-se por parte dos administrados ou terceiros interessados. Do contrário, todos os atos realizados pelos agentes administrativos correriam o risco de serem impugnados por espírito de chicana política, tão difundido nas democracias, e a atividade dos agentes públicos ficaria paralisada. A pretexto de assegurar o bom funcionamento dos serviços públicos, correr-se-ia o perigo de perturba-los (Gaston Jèze, Princípios generales del derecho administrativo, 1949, vol. III, p. 232).

Diversas são as modalidades mediante as quais se manifesta o desvio de poder, o que não impede o trabalho sistemático de agrupá-las em duas classes principais, distinguindo dois tipos de fins legais aos quais deve circunscrever-se a atividade administrativa: o fim de interesse geral, comum a todos os atos administrativos, e os fins particulares, peculiares a cada um dos atos (André de Laubadère, Traité élémentaire de droit administratif, 1953, p. 390).

Todo ato administrativo tem por escopo o interesse geral, público. É a regra a que está sujeita toda autoridade administrativa. Disto resulta que o desvio de poder é causa inegável de ilegalidade suscetível de afetar todos os atos administrativos, sem exceção alguma.

Mesmo que nenhum fim específico seja atribuído a determinada competência, sempre tal competência poderá ser acusada de desvio de poder quando atuar na perseguição de fim que não seja de interesse público. É o que se costuma exprimir algumas vezes, dizendo-se que em matéria de fim não existe nunca poder discricionário (André de Laubadère, Traité élémentarie de droit administratif, 1953, p. 390).

Se o administrador exercer os poderes de que está investido, quer num fim pessoal, quer num fim político, quer num fim religioso (Marcel Waline, Traité élémentaire de droit administratif, $6^{a}$ ed., 1962, ps. 142-143), está caracterizado, de modo insofismável, o desvio de poder.

O móvel pessoal, que afeta o fim do ato, pode ser o interesse econômico do autor do ato (Waline cita o caso, na França, de um Prefeito que regulamentara bailes e "dancings" da Comuna para combater a concorrência que faziam à sua hospedaria, (Traité élémentarie, $6^{\mathbf{a}}$ ed., 1952, p. 142, nota 2), ou qualquer tipo de sentimento, como a inimizade, o ódio, a vingança pessoal.

Móvel político é a decisão da autoridade para prejudicar ou eliminar adversário político.

Móvel religioso é qualquer medida, favorável ou contrária a determinada religião, em confronto com outra atingida pelos reflexos diretos do ato.

É o caso, por exemplo, ocorrido entre nós, de templo protestante desapropriado, não por utilidade pública, mas por motivos religiosos, o que tornou ilegal o ato expropriatório por desvio de poder, em razão de móvel religioso (cf. Revista dos Tribunais, vol. 129, p. 689: "Ilegal é o ato de expropriação de cemitério particular, já interditado pelo imperativo de lei estadual, inspirada na Constituição Federal de 1934, visando abranger uma ingreja contígua, para prestigiar, sob pretexto de apaziguar, uma luta religiosa, uma seita contra outra"). 
O interesse de terceiro, ou seja, a decisão destinada a favorecer um particular em detrimento de outro, configura também vício de fim, o que não quer dizer que a decisão favorável não possa, por acaso, coincidir com o interesse coletivo (Laubadère. Traité élémentaire de droit administratif, 1953, p. 390, nota 5), hipótese que de modo algum eiva o ato de nulidade por desvio de poder.

Se indício é qualquer coisa ou fato sensível que tem ou pode ter relação com outro fato (João Mendes de Almeida Júnior, Direito judiciário brasileiro, $3^{2}$ ed., 1940, p. 210), é bem de ver-se a importância que tal elemento adquire na comprovação do desvio de poder, quando se observa quão difícil é encontrar prova absolutamente irrefutável, que comprometa a autoridade administrativa geralmente bastante esclarecida e astuciosa para não deixar nenhum vestígio de sua intenção crimonosa, ocultando o móvel inspirador da medida.

Os autores costumam catalogar em suas obras diversos exemplos de traços que assinalam a conduta da autoridade administrativa, permitindo assim, através de índices, indiretos, concluir algo de positivo sobre o estado de ânimo que vicia a manifestação da vontade, inquinando o ato.

Assim, a precipitação com que a autoridade, nomeada ou eleita, assina a decisão, antes mesmo da posse, ordenando que seja executada no dia seguinte ao em que entrou em exercício; a inexistência real dos motivos invocados e, mais geralmente, a ausência de motivos plausiveis, o caráter sistemático de certas proibições, o caráter de certa medida geral que deveria ser particular (Marçal Waline, Traité élémentaire de droit administratif, $6^{\mathrm{a}}$ ed., 1952, p. 145).

A prova de desvio do poder tem de ser inequívoca. Assim, a demissão de funcionário a pretexto de falta de verba, mas na realidade por motivos políticos, fica evidenciada se, logo depois, a mesma autoridade admite outros funcionários, alguns inclusive para o cargo do funcionário demitido, de modo a levar a certeza ao espírito dos órgãos judiciários, convencendo-os de que o fim previsto em lei foi desvirtuado pelo agente, sacrificando-se o interesse público em prol de caprichos de natureza pessoal ou de outro interesse público não assinalado na lei.

Regra geral, é difícil encontrar "provas", ou mesmo "indícios", que revelem a intenção do administrador, ao editar o ato administrativo, deixando vestígios, mesmo leves, do "móvel" que impulsionou o editor da medida. Nesse caso, os sintomas, ou provas, é que revelarão "o mal", inserido em quadro clínico indiscutível (cf. nosso artigo Sintomas denunciadores do "desvio de poder", em Revista da Procuradoria-Geral do Estado de São Paulo, 1976, ps. 27 a 44).

Denominamos sintoma do desvio de poder qualquer traço, interno ou externo, direto, indireto ou circunstancial que revele a "distorção" da vontade do agente público ao editar o ato, praticando-o não por motivo ou interesse "público", mas por motivo "privado".

Internamente, o sintoma se revela na própria motivação do ato. Se a motivação é excessiva, insuficiente, deficente, inexistente ou contraditória, o desvio de poder é caracterizado pelo próprio exame dos elementos constantes do bojo do ato. Os próprios motivos, alegados pelo "administrador", permitem que se perceba, na edição do ato, a presença da intenção do "dominus". Nesse caso, a própria autoridade ("pela boca morre o peixe") é que fornece direta ou indiretamente a prova da 
ocorrência do desvio. Não é necessário sair do alegado, já que a intenção da autoridade emerge do exame dos elementos constantes do bojo do ato.

Se a motivação conflita com a que fundamenta outros atos, anteriores ou posteriores à edição do ato, ou se choca com fatos, ocorrentes antes ou depois da prática do ato, o desvio de poder ressalta pelo choque entre essas circunstâncias inconciliáveis.

Outras vezes, claro feixe convergente de indícios, para usar a expressão de Jean Rivero e Jean Waline, em colaboração (cf. Droit Administratif, $19^{\mathrm{a}}$ ed., 2002, p. 249), caracteriza o desvio ("a união faz a força"), já que cada um desses indícios, de per si, isoladamente, seria insuficiente para tipificar a "aberratio finis legis".

Por fim, as circunstâncias em que o ato é editado ("eu sou eu e minhas circunstâncias", de Ortega e Gasset, aplicado ao caso) podem constituir sintoma inequívoco do desvio de poder, como, por exemplo, quando a autoridade demonstra precipitação em praticar o ato, como no caso em que o Chefe do Executivo, mal toma posse, declara de utilidade pública o imóvel de inimigo seu ou demite do cargo desafeto político.

Desse modo, o ato administrativo, editado com desvio de poder, é suscetível de apresentar "indícios", "traços" ou "sintomas", que revelam a intenção deteriorada do administrador.

Tais sintomas permitem o delineamento de nítido quadro que demonstra a "distorção" ocorrida. Daí a relevância do "sintoma" ou "indícios", no diagnóstico do "desvio".

Diante de casos práticos, instado a manifestar-se, o Conselho de Estado italiano, em fins do século dezenove e inicio deste, seguindo a mesma orientação fixada pelo Conselho de Estado Francês, foi construindo, com admirável esforço e contínuo labor, a teoria do desvio de poder, enumerando depois, casuisticamente, as hipóteses concretas em que o diagnóstico daquela "disfarçada" ilegalidade poderia ser realizado (cf. Mortara, Comentário, $4^{a}$ ed., v. I., ps. 482 e segs., nota 1, e Alessio, Istituzioni di diritto amministrativo italiano, $4^{\mathrm{a}}$ ed., 1949, v. II, p. 245, nota 1).

Com apoio na jurisprudência do Conselho de Estado francês e italiano, bem como na consagração doutrinária dos autores mais representativos desses dois países, é possível apontar os traços sintomáticos ou sintomas, suficientes para impugnar-se $o$ ato administrativo perante a Administração ou perante o Judiciário, pedindo-se o reconhecimento do "desvio" e a conseqüente anulação da medida lesiva ao direito subjetivo público do administrado, em virtude da arbitrariedade do administrador.

Entre esses índices, indícios ou sintomas, é possível arrolar, como já dissemos no início deste artigo, os seguintes: "contradição do ato com atos posteriores"; "contradição do ato com atos anteriores"; "motivação exagerada"; "motivação contraditória"; motivação insuficiente"; "alteração dos fatos"; "ilogicidade manifesta"; "manifesta injustiça"; "disparidade de tratamento"; "derrogação de norma interna"; "precipitação com que o ato foi editado"; "inexistência, de fato, dos motivos apresentados pelo administrador para justificar a decisão tomada"; "desigualdade de tratamento dispensada aos interessados"; " caráter sistemático de certas proibições"; "caráter geral atribuído à medida que deveria permanecer particular"; 
"circunstâncias locais que antecederam a edição do ato", e, por fim, um "feixe convergente de indícios".

Examinemos, um a um, esses sintomas referidos, procurando exemplos ilustrativos do direito brasileiro, não só na jurisprudência já consagrada pelos nossos tribunais e sistematizada posteriormente, pela doutrina, como também na própria doutrina elaborada.

Dentre as várias hipóteses, inventariadas pela doutrina italiana (Zanobini, Corso di diritto amministrativo, $6^{\mathrm{a}}$ ed., 1960, vol. I, ps. 250-251, e Corso de diritto amministrativo, $6^{\mathrm{a}}$ ed., 1948, vol. II, ps. 142 a 144; Alessio, Istituzioni di diritto amministrativo, $4^{\text {a }}$ ed., 1949, vol. II, p. 244; Landi e Potenza, Manuale de diritto amministrativo, $2^{a}$ ed., 1963, ps. 272 a 275), a "contradição do ato da autoridade com atos seus posteriores" envolve o problema de descobrir-se, com nitidez, a efetiva vontade da autoridade, quando vários atos simultâneos ou sucessivos concretizam objetivos contraditórios entre si (Landi e Potenza, Manuale di diritto amministrativo, $2^{a}$ ed., 1963, p. 274).

Caso típico de "contradição flagrante do ato com atos posteriores" foi apreciado pelo Tribunal de Alçada de São Paulo, quando, certa vez, determinado Prefeito demitiu funcionário público, nomeado em caráter efetivo, a pretexto de que as finanças do Município periclitavam, em razão do excessivo número de servidores admitidos. Entretanto, menos de um mês depois, dezenas de nomeações eram feitas pela mesma autoridade que editara o ato demissório, inclusive duas para cargos de encarregado de serviço, de natureza e padrão iguais aos do agente público demitido.

O Tribunal, apreciando o caso, concluiu: "Na espécie, demitido o autor por força do ato que teria tido como finalidade, a economia dos cofres públicos, outras pessoas foram nomeadas para cargos idênticos. Houve, pois, desvio de poder. $\mathrm{O}$ ato demissório, assim, por mais esse fundamento deve ser considerado nulo, impondo-se, como consequiência, a procedência da ação" (TASP, 1961, rel. Rodrigues Alckmin em $R D A$ 70/172-174).

A "contradição do ato com manifestação anterior de vontade do mesmo órgão" é apontada por Zanobini (Corso di diritto amministrativo, 6a ed/. 1960, vol. I, p. 251) como sintoma inequivoco da ocorrência de desvio de poder. Assim, configuram exemplos concretos de desvio de poder, entre outros, (a) "a punição disciplinar aplicada a alguns funcionários em virtude de fato que, em circunstância anterior, a mesma autoridade não considerara punível; (b) a licença forçada ou demissão de funcionário por incapacidade, quando, pouco tempo antes, lhe eram confiados encargos delicados e importantes e fora manifestada a satisfação da autoridade pelo modo louvável com que o funcionário os houvera resolvido" (Zanobini, Corso di diritto amministrativo, $6^{\mathrm{a}}$ ed., 1960, vol. I, p. 251 e Aldo Bozzi, Instituzioni di diritto pubblico, $2^{\mathrm{a}}$ ed., 1966, p. 331).

É nos motivos determinantes do ato que o desvio de poder se revela (cf. Maurice Hauriou, Précis de droit administratif et de droit public, $11^{\mathrm{a}} \mathrm{ed}, 1927$, p. 421), afirma Hauriou.

Ora, a motivação, ou seja, a explicitação dos motivos que levaram a Administração a editar o ato (Alessi, Sistema instituzionale del diritto amministrativo, 1953, 
p. 257 e nosso Tratado de direito administrativo, $2^{\mathbf{a}}$ ed., 2002, vol. II, p. 227), pode ser "inexistente", "insuficiente", "exagerada" ou "contraditória".

Nesta altura, cabe o exame da motivação exagerada ou excessiva, típica do ato administrativo eivado de desvio de poder. Não convencido da autenticidade do ato, o administrador, como que temendo a força da opinião pública, defende-se " $a$ priori", justificando em demasia a medida editada.

Pietro Gasparri, no verbete "Eccesso di potere", com que ilustrou as páginas da Enciclopedia del diritto, vol. XVI, "sub voce", aponta, de modo expresso, a "superabundância" ou "excessividade" de motivação como um dos sintomas inequívocos do desvio de poder.

Muitas vezes, o excesso de poder pode ser revelado pela superabundância de motivação. Quando o editor do ato apresenta, como justificação, uma série infindável de fatos e de considerações prolixas e não concludentes, fundada é a suspeita de que a decisão decorre de uma opção, cujos verdadeiros motivos é preferível que se conservem ocultos (Pietro Gasparri, Enciclopédia del diritto, vol. XVI, "sub voce", "Eccesso di potere").

Em outra obra, Pietro Gasparri salienta que "cumpre não confundir a perplexidade ou contraditoriedade da motivação com a simples superabundância dos motivos adotados, quando estes não são incompatíveis entre si. Certo que também, em tais casos, pode surgir suspeita sobre a pureza da apreciação daquele que editou o ato. O órgão que tem motivo claro e suficiente para editar determinado ato não sente a necessidade de reforçar esse motivo com considerações acessórias; podendo pensarse, então, que, se o faz, é porque não se sente totalmente seguro com nenhum dos motivos tomados em si e por si, isoladamente" (Pietro Gasparri, Corso di diritto amministrativo, vol. III, "Le disorganizzazione e le disfunzione amministrative", 1956, p. 162).

Exemplo típico de decreto expropriatório, editado com desvio de poder, ocorreu, no Brasil, em 5 de julho de 1973, concernente ao ato publicado no Diário Oficial de Salvador, Bahia, no dia seguinte, declarando de utilidade pública, em caráter de urgência, para efeito de desapropriação, imóvel residencial particular, para que nele se instalasse escola-parque para crianças excepcionais.

Ao invés de declarar, para e simplesmente, a utilidade pública, em caráter de urgência, fundamentado-se no diploma expropriatório em vigor e capitular a hipótese no respectivo inciso do art. $5^{\circ}$, do Decreto-Lei $n^{\circ} 3.365$, de 21 de junho de 1941 , o editor do ato estendeu-se nos "considerandos", superabundantemente, explicando e reexplicando a necessidade da medida, o que é suficiente para caracterizar o desvio de poder, por "excesso" ou "superabundância" de motivação, como demonstrou, de maneira irretorquível, o professor Manoel Gonçalves Ferreira Filho, solicitando a manifestar-se a respeito, mediante Parecer jurídico (cf. Parecer, em RDA 118/431). "Corrobora essa conclusão, a presença de um dos sinais do abuso de poder. A motivação do desvio é excessiva. Ora, nisso está, segundo a lição de Gasparri, um dos sintomas do excesso ou desvio de poder" (Manoel Ferreira Filho, Parecer, em RDA 118/435).

"Motivação contraditória" pode ser outro dos sintomas do desvio de poder. 
Com efeito, o ato administrativo exprime a vontade da Administração. Nos motivos, está a razão da decisão. A motivação contraditória deixa o intérprete perplexo a respeito da verdadeira razão inspiradora do administrador. A doutrina italiana é unânime ao apresentar a motivação contraditória como sintoma inequívoco da presença do desvio de poder (cf. Alessi, Diritto amministrativo, 1949, vol. I, p. 293; Zanobini, Corso diritto amministrativo, $6^{\text {a }}$ ed., 1948, vol. II, p. 144, e Corso di diritto amministrativo, $6^{\text {a }}$ ed. 1950, vol. I, p. 251; Landi e Potenza, Manuale di diritto amministrativo, $2^{\mathrm{a}}$ ed., 1963, ps. 273-274; Ugo Forti, Lezioni di diritto amministrativo, 1950, vol. II, p. 192; Arnaldo de Valles, Elementi di diritto administrativo, $3^{\mathrm{a}}$ ed., 1965, p. 171).

A ilogicidade ou contraditoriedade do ato é revelada pelo contraste insanável de várias partes da medida, como, por exemplo, entre os diversos incisos da motivação ou entre a motivação e o dispositivo. Assim, a deliberação de Comissão Disciplinar que, depois de haver excluído de responsabilidade o funcionário por inexistência de culpabilidade, acaba propondo depois, no Parecer, a aplicação de pena (Landi e Potenza, Manuale di diritto amministrativo, $2^{\mathrm{a}}$ ed.., 1963, ps. 273-274).

Zanobini emprega também a expressão ilogicidade manifesta para designar "a falta de nexo lógico entre os vários motivos ou entre a motivação e o dispositivo do ato" (Corso di diritto amministrtivo, $6^{\mathbf{a}}$ ed., 1950, vol. I, p. 251, e Corso di diritto amministrativo, $6^{\mathrm{a}}$ ed., 1948, vol. II, p. 144).

Arnaldo de Valles menciona este sintoma sob a epígrafe de "falta de nexo lógico entre premissas e ato", hipótese em que "o ato se apresenta com causa que não é dedução lógica dos motivos e se funda em contradição lógica que pode ser protegida pelo direito" (Elementi di diritto amministrativo, $3^{\mathrm{a}}$ ed., 1965, p. 171).

No citado caso da desapropriação de mansão particular, na Bahia, para instalação, no imóvel, de escola-parque para excepcionais, o desvio de poder ficou também caracterizado pela ilogicidade manifesta entre dois dos motivos mencionados, na justificação, o que foi assim apreciado pelo professor Manoel Gonçalves Ferreira Filho (Parecer, em RDA 118/435), manifestando-se a respeito: "A menção deste segundo motivo serve, entretanto, para colocar sob suspeita o primeiro, se outras razões não houvesse para tanto. Como duas cogitações tão dispares, o interesse dos excepcionais e a preservação da beleza citadina, podem confluir numa expropriação, sem que se suspeite de que tais motivos foram indevida e falsamente invocados, ou, ao menos, um deles?

Desse modo, a contradição flagrante entre dois motivos expressos é sintoma que deve ser levado em conta para o diagnóstico do desvio de poder.

Motivação insuficiente é outro sintoma apresentado pela doutrina (Alessi, Diritto amministrativo, 1949, vol. I, p. 293; Aldo Bozzi, Istituzioni di diritto pubblico, $2^{\mathbf{a}}$ ed., 1966, p. 331) para a positivação de ocorrência de desvio de poder, como, por exemplo, no Brasil, se decretasse desapropriação apenas fundada, genericamente, na utilidade pública, deixando o expropriante de indicar, de modo específico, a razão concreta, capitulada no inciso correspondente do Decreto-Lei $n^{\circ} 3.365$, de 21 de junho de 1941.

A doutrina italiana aponta o "travisamento" (= alteração, adulteração, deformação) dos fatos como sintoma típico do desvio de poder (Cino Vitta, Diritto 
amministrativo, $3^{\text {a }}$ ed., 1949, vol. I, p. 431; Aldo Bozzi, Istituzioni di diritto pubblico, $2^{a}$ ed., 1966, p. 331; Alessi, Diritto amministrativo, 1949, p. 293; Zanobini, Corso de diritto amministrativo, $6^{\text {a }}$ ed., 1950, vol. I, p. 251 e Corso, $6^{a}$ ed., 1948, vol. II, p. 143; Landi e Potenza, Manuale di diritto amministrativo, $2^{\mathrm{a}}$ ed., 1963, p. 273; Alessio, Istituzioni di diritto amministrativo italiano, $4^{\text {a }}$ ed., 1949, vol. II, p. 245, nota I, citando Mortara e Lentini, Istituzioni di diritto amministrativo, 1939, vol. II, p. 20; Ugo Forti, Lezioni, 1950, vol. II, p. 192).

"A mim me parece", escreve Cino Vitta, "que a alienação (= "travisamento") pode melhor ser considerada como um dos sintomas que acusarão a existência do desvio, entendendo-se como "travisamento" a averigação ou a avaliação dos fatos, em geral, de modo artificial, com a finalidade de submetê-los à aplicação de preceito de lei, sob o qual, de outro modo, não teriam sido enquadrados. Célebre o exemplo de ordem de fechamento de edifício de habilitação por insalubridade, alterando-se para isso os fatos, quando na verdade a casa é modelo de salubridade. Mais facilmente a alteração pode confundir-se com o vício de inoportunidade, no mérito do ato administrativo, e os limites deles vão assinalados com refinado senso jurídico. $\mathrm{O}$ ato é inoportuno quando não pareça justificado por suficientes motivos de fato, embora subsistindo alguns dos fatos que a lei levou em conta, ao passo que é viciado por "travisamento" (= alteração), quando nenhum dos fatos apresentados corresponde à realidade e esteja assim ausente toda exigência de interesse público" (Cino Vitta, Diritto amministrativo, $3^{\text {a }}$ ed., 1949, vol. I, ps. 431-432).

"Ocorre a alteração dos fatos quando, na motivacão do ato, são afirmados, como seus pressupostos, fatos insustentáveis, ou são negados fatos reais. À alteração é equiparada a consideração dos fatos afirmados; trata-se, ao contrário, de valoração inoportuna ou injusta, saindo-se do vício de legitimidade para entrar no vício de mérito" (Zanobini, Corso, 6a ed., 1950, vol. I, p. 251). "Ocorre o desvio de poder por alteração (= "travisamento") dos fatos todas as vezes que o ato é editado sobre pressuposto da existência ou da inexistência dos fatos, que dos atos resultam, de modo certo, inexistente ou subsistente. Ao contrário, não se dá o "Travisamento", quando o ato resulta de apreciação discricionária da Administração a respeito de fatos existentes. Um juízo sobre tal apreciação se resolve em exame do mérito" (Zanobini, Corso, 6a ed., 1948, vol. II, p. 143).

Com base na jurisprudência italiana, Aldo Bozzi ressalta que a circunstância de ocorrer o "travisamento" (ato baseado em pressupostos da existência dos fatos que resultam, ao contrário inexistentes ou existentes) é um dos sintomas típicos do desvio de poder (cf. Istituzioni, $2^{\mathrm{a}}$ ed., 1966, p. 331).

Landi e Potenza ressaltam que "a alteração e a valoração errônea dos fatos influem sobre a vontade, ocorrendo quer quando a Administração, ao editar o ato, considerou, de modo errôneo, como existentes, fatos inexistentes, ou vice-versa; quer quando atribuiu aos fatos significado errôneo, ilógico ou irracional. Considera-se viciado de alteração dos fatos, por exemplo, o ato que aceita a demissão de funcionário, baseado no pressuposto errôneo que o funcionário a tenha apresentado; considera-se de errônea valoração o ato que considera injustificada a ausência do funcionário, quando já foi devidamente comprovado que ela ocorreu em virtude de doença. Não deve confundir-se com valoração errônea a valoração inoportuna ou 
injusta, que pode originar vício de mérito, mas não vício de legitimidade. Assim, não se verifica erro, mas apenas inoportunidade ou injustiça, se a Administração, apurando de modo preciso as circunstâncias de uma infração disciplinar, lhe atribui, para fins de aplicação da pena, excessiva gravidade" (Landi e Potenza, Manuale di diritto amministrativo, $2^{\mathrm{a}}$ ed., 1963, p. 273).

Silvio Lessona enquadra esta hipótese no erro de fato, consistente em "haver introduzido, na base do ato administrativo, fatos inexistentes ou em haver considerado inexistentes atos existentes" (Introduzione al diritto amministrativo e sue strutture fondamentali, 1960, p. 87).

A ilogicidade manifesta - perplexidade ou incogruência dos motivos invocados para suporte do ato - é outro dos sintomas apresentados pelos autores para a denúncia do desvio de poder (Aldo Bozzi, Istituzioni di diritto pubblico, $2^{2}$ ed., 1966, p. 331; Zanobini, Corso, $6^{a}$ ed., 1950, vol. I, p. 251 e Corso, $6^{a}$ ed., 1948, vol. II, p. 144). Consiste a ilogicidade manifesta "na ausência de nexo lógico, entre os vários motivos ou entre a motivação e o dispositivo do ato" (Zanobini, Corso, $6^{\mathbf{a}}$ ed., 1950, vol. I, p. 251), ou "na ausência de nexo lógico entre os motivos e o dispositivo do ato ou na contradição entre as várias partes dele" (Zanobini, Corso, 6ª ed., 1948, v. II, p. 144).

Silvio Lessona também inclui a ilogicidade do ato entre os sintomas do desvio de poder, "quer quando na medida se dispõe em desacordo com os motivos adotados para justificar o próprio ato, quer quando os motivos, sendo complexos ou contraditórios, não permitem saber se a administração agiu de modo correto para a realização do interesse público" (Introduzione al diritto amministrativo e sue strutture fondamentali, 1960, p. 87).

A injustiça manifesta, acolhida pela jurisprudência italiana para a denúncia do desvio de poder, designa a diversidade ou disparidade de tratamento atribuída a situações idênticas (Zanobini, Corso, $6^{\mathrm{a}}$ ed., 1948, vol. II, p. 143) ou, em outros casos, o gravame imposto no interesse privado, sem a suficiente razão de interesse público. Como se vê, no primeiro caso, o vício pode reduzir-se ao da contradição, no segundo caso, tal vício parece invadir o campo do mérito administrativo e a decisão não pode ser aprovada. Só quando a ausência de interesse público pode ser demonstrada com base em elementos que integram o ato ou atos a ele ligados, pode o vício denominar-se de ilegitimidade e reconduzir-se ao desvio de poder (Zanobini, Corso, $6^{a}$ ed., 1948, vol. II, ps. 143-144).

Landi e Potenza observam que este sintoma é raríssimo, porque, regra geral, injustiça é vício de mérito. Como exemplo, apresenta o caso da dispensa de serviço de funcionário por motivo de escasso rendimento, quando, na realidade, a causa dessa anomalia reside em acidente originado do próprio serviço (Manuale di diritto amministrativo, $2^{\mathbf{a}}$ ed., 1963, p. 274).

Admite-se esta modalidade de desvio de poder, quando se considera que a Administração deve agir como o "homo eticus", devendo, então, exercer-se o poder que lhe é atribuído de acordo com a mais estrita eqüidade, ou seja, a "imparcialidade da Administração", de que fala o artigo 97 da Constituição italiana (cf. Silvio Lessona, introduzione al diritto amministrativo e sue estrutlure fondamentali, 1960, p. 88). 
Landi e Potenza, ao contrário de Zanobini que identifica os sintomas pela manifesta injustiça e disparidade de tratamento (Zanobini, Corso, $6^{\text {a }}$ ed., 1948, vol. II, ps. 143 e 144), mencionam as duas hipóteses, ilustrando-as e definindo-as de modo diverso e bem nítido. Na realidade, a disparidade de tratamento é espécie ou forma de injustiça, verificando-se "quando a Administração, em presença de perfeita identidade de condições subjetivas e objetivas, adota medidas diferentes, com na hipótese em que, na apuração de determinada infração, disciplinr e de grau igual de responsabilidade, um dos funcionários seja absolvido e o outro punido" (Landi e Potenza, Manuale di diritto amministrativo, $2^{\mathrm{a}}$ ed., 1963, p. 274).

Aldo Bozzi nota que manifesta e grave injustiça é situação que se inclui em outras hipóteses (ilogicidade, disparidade de tratamento) ou constitui vicio de mérito e não de le gitimidade, já que implica apreciação do conteúdo e da oportunidade do ato (Istituzioni di diritto pubblico, $2^{\text {a }}$ ed., 1966, p. 331). Cf., ainda, Ugo Forti, Lezioni di diritto amministrativo, 1950, vol. II, p. 192).

As normas internas (cf. Silvestri, L'attività interna della pubblica amministrazione, 1950, p. 186) não se equiparam, é claro, às normas jurídicas no sentido substancial e, assim, sua transgressão não pode entrar no conceito de violação da lei (cf. Landi e Potenza, Manuale di diritto amministrativo, $2^{\mathrm{a}}$ ed., 1963, p. 274). Ora, " a derrogação injustificada, em um caso particular, de disposições internas de caráter geral, editadas pela Administração, como, por exemplo, a violação de circulares, é também típico sintoma de desvio de poder" (Aldo Bozzi, Istituzioni di diritto pubblico, $2^{\mathrm{a}}$ ed., 1966, p. 331).

"Quando a Administração disciplinou a própria atividade com tal espécie de normas, entende-se que tenha individuada as modalidades mais oportunas para a consecução do interesse público e, pois, se tenha autolimitado, no sentido de não poder agir, nos casos particulares, de modo diverso daquele que estabelecera, na norma interna (circular, instrução), de modo geral" (Landi, e Potenza, Manuale di diritto amministrativo, $2^{\mathrm{a}}$ ed., 1963, p. 275).

De acordo com o princípio "suporta a lei que fizeste", erigida uma norma como diretriz de determinado setor da Administração, ela vale de modo igual para todos, não se admitindo, a não ser por desvio de poder, seja derrogada para atender a caso particular.

Os diferentes sintomas acima, catalogados e analisados pela doutrina italiana, representam a síntese de casos concretos, decididos pelo Conselho de Estado da Itália.

A doutrina gaulesa, também fundamentada em casos apreciados pelo Conselho de Estado da França, procura sistematizar as hipóteses dos traços reveladores do desvio de poder, denominados pelos autores franceses de "indícios", "índices" ou "provas".

Waline observa que "é fácil, com efeito, compreender que quando o administrador usa dos poderes de que dispõe para atingir fim inconfessável não tem a ingenuidade de confessá-lo. Disfarça, então, os verdadeiros motivos do ato e apresenta oficialmente pretexto legal. Trata-se de desmascarar o embuste, o que nem sempre é fácil" (Waline, Traité élémentaire de droit administratif, $6^{a}$ ed., 1952, p. 144), "mas muito mais difícil ainda é conhecer a verdadeira intenção do autor do ato cuja legalidade é discutida. Com efeito, quando a autoridade administrativa 
comete o desvio de poder, é porque agiu de má fé, sabendo muito bem que traiu a intenção do legislador, pelo que não tem a inocência de indicar as razões inconfessáveis que a inspiraram, devendo o juiz analisar todas as circunstâncias que cercaram a edição do ato. Essa prova é dificílima de ser feita" (Waline, Droit administratif, $9^{\mathrm{a}}$ ed., 1963, p. 481 ).

Entre os indices ou sintomas denunciadores do desvio de poder a doutrina francesa, baseada em decisões do Conselho de Estado, aponta os seguintes: (a) pressa com que o ato foi editado, (b) inexistência dos motivos apresentados pelo administrador para justificar a decisão tomada, (c) desigualdade de tratamento dos interessados, (d) caráter sistemático de certas interdições, (e) caráter geral atribuído à medida que deveria permanecer particular, (f) circunstâncias locais que antecederam a edição do ato.

"No plano prático", salienta Francisco Paul Bénoit, "o desvio de poder suscita delicadíssimo problema de prova. Tratando-se de perscrutar intenções, a dificuldade não causará espanto. Com muita sabedoria o juiz administrativo exige provas, de qualquer modo, palpáveis, quer resultantes da própria redação do ato, hipótese rara, mas que pode ocorrer porque, inadvertidamente, o autor da decisão fornece, às vezes, elementos que caracterizam a ilegalidade de suas intenções, quer dos dossiê, ou seja, do cotejo do ato impugnado com outros documentos" (Le droit administratif français, 1968, p. 545).

Jean Rivero e Jean Waline observam que uma das dificulades para caracterizar o desvio de poder radica "no terreno da prova. A intenção é elemento psicológico, difícil de aprender, salvo quando o autor o declara abertamente, o que será tanto mais raro quanto menos confessável" (Droit administratif, $19^{\mathrm{a}}$ ed., 2002, ps. 249-250, e Lemasurier, "La preuve dans le détournement de pouvoir", na Revue de droit public et de la science politique, 1959, p. 36).

"Mais difícil de provar do que os outros vícios do ato administrativo, porque se trata de descobrir a intenção psicológica de seu autor" (Vedel, Droit administrtif, $5^{a}$ ed., 1973, p. 609), o desvio de poder admite a prova indireta, já que o administrador raramente iria contribuir com prova direta, confessando o motivo real ou confidenciando as intenções que o impeliram a editar o ato (Vedel, Droit administratif, $5^{a}$ ed., 1973, p. 610).

Pressa na edição do ato é sintoma acolhido pelo Conselho de Estado Francês, como ocorreu, por exemplo, na decisão proferida em 3 de março de 1939, quando diretor que acabara de ser nomeado e nem ainda tomara posse do cargo assinou o ato e mandou executá-lo com precipitação anormal, no dia seguinte ao que fora empossado (Waline, Traité élementaire de droit administratif, $6^{\mathrm{a}}$ ed., 1952, p. 144 e Droit administratif, $9^{\text {a }}$ ed., 1963, p. 482).

Inexistência dos motivos alegados pelo administrador, como, por exemplo, proibição de procissões, nas ruas, sob o falso pretexto de que trariam perturbações à ordem pública, é outro sintoma do desvio de poder, apontado pela doutrina francesa, com base na realidade submetida à decisão do Conselho de Estado (decisão de 18 de agosto de 1944, citado por Waline, Traité élémentaire, $6^{\mathbf{a}}$ ed., 1952, p. 144).

Aos demais sintomas, arrolados no início deste parágrafo, a doutrina gaulesa acrescenta outros - peças escritas, circunstâncias nas quais interveio o ato, inexa- 
tidão dos motivos alegados (cf. Rivero-Waline, Droit administratif, $19^{\mathrm{a}}$ ed., 2002, p. 249) - que deixam transparecer o fim verdadeiro que o administrador pretendia alcançar. "O magistrado procura menos uma prova manifesta do que uma convicção, que pode resultar de um feixe de indícios convergentes" (Rivero e Waline, Droit administratif, $19^{\mathrm{a}}$ ed., 2002, p. 249).

Diante dos tribunais brasileiros têm sido levados para a apreciação inúmeros atos administrativos eivados de desvio de poder e, em especial, decorrentes do exercício do poder de polícia, da hierarquia e da licitação.

O poder de polícia, incidindo sobre inúmeras áreas de exercício de direito do particular, inclusive sobre as faculdades inerentes ao direito de propriedade, adquire especial relevância no que se refere ao decreto expropriatório, ato administrativo que sob disfarce do interesse público serve para a satisfação dos caprichos ocultos e pessoais do administrador.

O poder hierárquico, recaindo sobre todo o funcionalismo, serve de constante pretexto para a prática do desvio de poder, já que oferece amplas possibilidades para que o superior cometa abusos sobre subordinados, aplicando-lhes sanções por motivos pessoais e não objetivando o bom andamento do serviço público.

Ao contrário, porém, do que se verifica com os tribunais dos países que admitem o contencioso adminisrativo, entre os quais a França e a Itália, cujos magistrados, especializados em questões administrativas, reconhecem de imediato a presença da figura do desvio de poder, mediante a interpretação rigorosa de "índices", "indícios", "sintomas", "feixes convergentes de indícios", que lhes fornecem elementos para a convicção, por ocasião do ato de julgamento no Brasil, país em que vigora o princípio da "una lex, una jurisdictio", o desvio de poder é mais intuído, de maneira global, do que diagnosticado mediante a análise de índices objetivos, concretos, denunciadores da arbitrariedade.

Sendo a intenção elemento de difícil apreensão, a não ser quando o autor o revela por inadvertência, de modo espontâneo, o diagnóstico do desvio de poder tem de ser realizado pela prova indireta, refletida nos sintomas repontáveis aqui e ali, denunciados pela parte prejudicada e apreciados pelo juiz.

No caso concreto já citado (TASP, 1961, em RDA 70/172), o abuso de hierarquia culminou com a demissão ilegal, mas o colegiado julgador, com fundamento no sintoma indiscutível - "contradição do ato com atos posteriores"-, anulou o ato demissório, editado com desvio de poder, já que a motivação, base no ato (economia do erário), entrava em choque com providência posterior (admissão de outros funcionários, inclusive para o mesmo cargo), o que configura sintoma inequívoco do arbítrio administrativo, traduzido na regra dos "dois pesos, duas medidas".

Em outro caso concreto, também já mencionado (o caso da Bahia), o arbitrio administrativo culminou com decreto expropriatório, fundado em móvel pessoal, objetivando vindita, revelado pelo sintoma típico da motivação excessiva, superabundante, prolixa, arquitetada para disfarçar sob o manto legal do interesse público as intenções privadas e inconfessáveis do administrador vingativo.

Procuramos, nesta altura, aproveitar a experiência francesa e italiana, consagrada pelo Conselho de Estado daqueles países e exposta depois pela doutrina. Con- 
frontando tais resultados com a realidade brasileira é possível um melhor entendimento desta "figura iuris" do direito administrativo, demitida hoje, sem reserva, entre nós.

Se desvio de poder é o uso indevido que o administrador faz do poder discricionário de que é detentor para concretizar "fim" diferente daquele que a lei fixara, o ato administrativo, editado com essa anomalia, é nulo, mas a prova da ilegalidade nem sempre é possível e, por vezes, mostra-se difícil, porque tem de revelar aspecto psicológico do autor, assim como certas moléstias insidiosas eu se ocultam ante os olhos perscrutadores do médico, só se revelando, mediante análise e interpretação de índices ou traços indiretos, assim também cumpre ao interprete do ato administrativo, eivado de desvio de poder, chegar ao momento de interioridade da autoridade arbitrária, disfarçado sob o manto inatacável da legalidade.

$\mathrm{O}$ "animus" do administrador, por mais arraigado que seja, pode ser denunciado por sintomas indiscutíveis, inventariados pela doutrina clássica de outros países e assim enumerados: (a) contradição do ato com atos ou medidas posteriores, (b) contradição do ato com atos ou medidas anteriores, (c) motivação excessiva, (d) motivação contraditória, (e) motivação insuficiente, (f) alteração (= "travisamento") dos fatos, (g) ilogicidade manifesta, (h) injustiça manifesta, (i) disparidade de tratamento, (j) derrogação, de norma interna, (l) precipitação na edição do ato, (m) caráter sistemático de certas proibições, $(\mathrm{n})$ circunstâncias locais que precederam a edição do ato, (o) convergência de feixe de indícios, (p) caráter geral dado à medida que deveria ter permanecido particular.

Um (ou mais de um) desses traços basta para o diagnóstico do desvio de poder. O sintoma é a prova indireta do arbítrio administrativo, concretizado na figura do desvio de poder.

Denunciado o desvio de poder pela parte prejudicada, a autoridade judicante pode motivar a razão de decidir em um dos sintomas acima enunciados, inventário empreendido pela mais autorizada doutrina estrangeira, com base em casos concretos, julgados, em definitivo, pela mais alta instância dos tribunais administrativos.

A prova do desvio de poder tem de ser inequívoca (Waline, Traité élémentaire de droit administratif, $6^{a}$ ed., 1952, p. 145), de modo a levar a certeza ao espírito dos órgão judiciários, convencendo-os de que o fim previsto em lei foi "desvirtuado" ou "distorcido" pelo agente, sacrificando-se o interesse público em prol de caprichos de natureza pessoal do administrador. A análise cuidadosa de um ou de vários sintomas, aqui relacionados, permite a feitura de diagnóstico científico da psicologia do administrador, o que leva à tipificação do desvio de poder.

Ao contrário do que ocorre com a maioria dos institutos jurídicos atuais, que lançam suas mais remotas raízes no direito romano, o desvio de poder é fruto de elaborações doutrinárias bastante recentes, já que remontam às últimas décadas do século vinte.

Criação inequívoca do Conselho de Estado francês (Gaston Jèze, Princípios generales del derecho administrativo, trad. argentina, 1948, vol. I, p. XXXVII, "Prólogo" do autor, e Waline, Traité élémentaire, 6a ed., 1952, p. 144), de origem, pois, jurisprudencial, a teoria do desvio de poder surge no cenário jurídico para coibir abusos, inerentes, aliás, não apenas à natureza humana e ao egoísmo dos 
indivíduos, como também aos governantes e agentes públicos (Gaston Jèze, Princípios generales del derecho administrativo, trad. argentina, 1949, vol. III, p. 79).

Mais uma vez iria patentear-se um traço típico do direito administrativo da França, fruto da elaboração pretoriana do Conselho de Estado, cuja jurisprudência, sobretudo em materia de excesso de poder, substitui a colaboração que o legislador e a doutrina emprestam à construção dos institutos deste ramo do direito, em outros países.

Cumpre, portanto, assinalar com precisão o caso concreto - caso Lesbats que, levando o Conselho de Estado a manifestar-se, deu como conseqüência a acolhida do desvio de poder ("détournement de pouvoir"), como vício do ato administrativo bastante para permitir fosse invocado o "remedium iuris" anulatório competente - o recurso por excesso de poder ('recours por excès de pouvoir') para fulminar, irremediavelmente, $o$ ato viciado.

Prefeito a quem texto legal anterior conferira poderes para regular o estacionamento e circulação de veículos públicos e particulares, destinados ao transporte de pessoas e mercadorias, nos pátios anexos às estações rodoviárias, com fins de polícia e com finalidade de manter a boa ordem nos lugares destinados ao uso público, passou a usar abusivamente de tais poderes, a fim de assegurar o monopólio dos transportes de empresa particular.

$\mathrm{Na}$ Argentina, não obstante haja divergência, na doutrina, sobre quem deva ser o juiz fiscalizador do desvio de poder, o instituto, em si, é admitido pelos autores. Assim, são favoráveis: Jorge Tristan Bosch, Tribunales Judiciales o tribunales administrativos para juzgar a la administración publica?, 1951, p. 150; Felix Sarría, Derecho administrativo, $4^{\text {a }}$ ed., 1950, vol. II, p. 209; Rafael Bielsa, Sobre lo contencioso administrativo, $2^{\mathrm{a}}$ ed., 1954, p. 91. No Uruguai, Enrique Sayagúes Laso ressalta a importância do instituto, admitindo-o (Tratado de derecho administrativo, 1953, vol. I, p. 449). Na Colômbia, Eustogio Sarría admite a existência do desvio de poder que se verifica "quando o agente, agindo com competência, se afasta do fim previsto na norma ou no motivo, origem da mesma competência, ou seja, quando o ato não se harmoniza com o fim ou com a necessidade que se pretende alcançar" (Derecho administrativo, $3^{a}$ ed., 1957, ps. 38-39). no Chile, Patrício Aylwin, Manual de derecho administrativo, 1952, p. 152. No México, Gabino Fraga frisa que "se se descobre que se trata de fim não sancionado pela lei, o ato deve ser privado de seus efeitos" (Derecho administrativo, $7^{\mathrm{a}}$ ed., 1958, p. 184).

Explora Marcel Waline a criação do desvio de poder pela timidez dos tribunais judiciários, receosos de atentarem contra o princípio da separação das autoridades administrativas e judiciárias. Eis uma primeira razão pela qual a jurisprudência sobre o desvio de poder é criação original do Conselho de Estado (Traité élémentaire, $6^{a}$ ed., 1952, p. 144).

Waline escreve: “... por motivo de importantes lacunas do direito escrito, a jurisdição administrativa foi compelida a consagrar pela jurisprudência numerosas regras que passaram a ter valor consuetudinário; formou-se, desse modo, um espécie de direito pretoriano" (traité élémentaire de droit administratif, $6^{2}$ ed., 1952, p. 12). No mesmo sentido, Maurice Hauriou: "Toda esta jurisprudência é de configuração pretoriana, sobretudo em matéria de excesso de poder" (Précis de droit administratif 
et de droit public, p. 711, citado por Orlando, Primo Trattato, vol. III, p. 801, nota 1). Esclarece Rafael Bielsa: O recurso de anulação é, praticamente, notável criação da jurisprudência do Conselho de Estado, motivo por que é considerado de cunho "pretoriano", pois este alto tribunal o elaborou e definiu de maneira análoga - não idêntica - à que empregava o pretor romano quando criava às ações úteis na época de maior desenvolvimento do direito" (Derecho administrativo, $5^{\text {a }}$ ed., 1955, vol. I, ps. 3-4 e cf. Laubadère, Manuel de droit administratif, $4^{\mathrm{a}}$ ed., 1955, p. 17).

Anteriormente ao caso Lesbats, 1864, que teve extraordinária repercussão, costumavam os autores mencionar o caso Vernes, decidido 6 anos antes (16 de maio de 1858). "In concreto", o caso Lesbats é o seguinte: o Prefeito da cidade francesa de Fontainebleau proibiu que um motorista estacionasse o ônibus no pátio interno da estação daquela localidade. Baseava-se a proibição no propósito de assegurar o cumprimento do contrato celebrado entre a empresa ferroviária e outro proprietário de ônibus, pelo qual só este último teria o direito de estacionamento e desembarque. Havia texto de lei anterior de 15 de novembro de 1846, que conferia à autoridade poderes para regular o estacionamento e circulação de veículos, mas o Conselho de Estado anulou a decisão do Prefeito, porque este não podia exercer seu poder de polícia para fins estranhos aos da manutenção da ordem e da organização do trânsito (Conselho de Estado, 15 de fevereiro de 1864, Sirey, Refonte, t. 9, III, p. 46). Mais tarde, como o Prefeito cumprisse a sentença pela metade, editando nova regulamentação restritiva, também esta foi anulada por desvio de poder (Conselho de Estado, 7 de junho de 1864, Sirey, Refonte, t. 9, III, p. 47). Citado através de Leon Aucoc, Conférences sur l'administration et le droit administratif, 1869, vol. I, ps. 403-404, e Enrique Sayagués Laso, Tratado de derecho administrativo, 1953, vol. I, p. 450, nota 1 .

Tal determinação foi anulada pelo Conselho de Estado francês por excesso de poder, porque o Prefeito usara de sua autoridade para fim diverso daquele que a lei tivera em mira (Oreste Ranelletti, Teoria degli atti aministrativi special, $7^{\mathrm{a}}$ ed., 1945, p. 81).

A importância da decisão Lesbats está no fato de que a autoridade judiciária já tinha declarado por duas vezes legal o ato do Prefeito e o Conselho de Estado o havia anulado duas vezes por excesso de poder.

O juiz ordinário e o administrativo tinham, ambos, razão, considerando o ato com critérios de juízo inerentes a cada caso (Oreste Ranelletti, Teoria degli atti amministrativi speciali, p. 81, nota 6). Comentando caso semelhante, escreve Maurice Hauriou: "Não pode a polícia do domínio público ser empregada para favorecer empresas particulares e criar verdadeiros monopólios de fato. Assim, foi anulada a decisão que proibia o estacionamento em via pública de qualquer veículo, exceto os de determinado concessionário" (Conselho de Estado, 2 de agosto de 1870, caso Bouchardon, apud Hauriou, Précis de droit administratif et de droit public, $6^{a}$ ed., 1907, p. 453).

Do mesmo modo, foi anulado por excesso de poder o ato de Prefeito que, para assegurar ao Estado o monopólio de águas minerais, proibiu que o proprietário vendesse as próprias águas, não obstante fossem estas puras. $\mathrm{O}$ ato estava viciado de excesso de poder, porque o Prefeito usara de sua autoridade para escopos fiscais, 
mas o poder que a lei lhe dera era para fins de polícia sanitária (Orestes Ranelletti, Teoria degli atti amministrativi speciali, p. 81).

Examinemos a orientação de nossa jurisprudência administrativa.

Não admite o direito brasileiro o instituto do contencioso administrativo. Vigora entre nós o sistema judiciário: "una lex”, "una jurisdictio". Falta-nos, pois, uma Corte especializada, como o Conselho de Estado francês, italiano ou belga, com funções judicantes.

Nem por isso, entretanto, está ausente do sistema brasileiro copiosa e importante jurisprudência, constituída de decisões dos órgãos do Poder Judiciário, atuantes nos diversos Estados (Tribunais de Justiça e Alçada) e na esfera Nacional (Supremo Tribunal Federal e Superior Tribunal de Justiça).

Decidindo essas Cortes os casos em que a matéria é administrativa, fornecem elementos importantes para o estudo de problemas como o que estamos examinando.

Inversamente ao que ocorre na França e na Itália, em que a teoria do desvio de poder é de cunho eminentemente jurisprudencial, ali nascendo, desenvolvendo-se e adquirindo suas linhas pecisas, não são muitos entre nós os arestos que acolhem a figura em apreço, como razão de decidir, esforçando-se, neste particular, a doutrina e despontando com relativa timidez, aqui e ali, em importantes decisões, principalmente em casos de poder de polícia, demissão de funcionário e licitação.

Uma das mais antigas manifestações da jurisprudência, que conseguimos localizar, no Brasil versou sobre evidente caso de desvio de poder, que ocorreu em 1904 (ver Amaro Cavalcanti, Responsabilidade civil do Estado, 1905, p. 606, nota 189). O segundo caso ocorreu em 1940 e envolveu matéria desapropriatória, à primeira vista por interesse público, realmente por motivo religioso (cf. Revista dos Tribunais, 129; 689-708).

Tratava-se de autoridade municipal pernambucana que decretara a desapropriação de cemitério particular, abrangendo, no mesmo ato administrativo, templo evangélico anexo e, para isso invocara o art. 122, inciso 5, da Carta Constitucional de 1937, que diz: “Os cemitérios terão caráter secular e serão administrados pela autoridade municipal."

$\mathrm{Na}$ aparência, o ato é legal. Preenche os requisitos de fundo e forma indispensáveis para ser válido, mas a prova demonstra que o fim a alcançar e diverso do apresentado. A autoridade municipal, embora competente, usara os poderes discricionários que a lei lhe conferira para objetivos inconfessáveis, disfarçados sob a capa da legalidade.

Com efeito, o Chefe do Executivo Municipal, de convicção católica, imiscuindo-se em luta religiosa local, traduzir veladamente o sentimento da maioria da população, também católica, procurando desapropriar o templo protestante, desviando a finalidade do ato que, abusivamente, deixava de lado o interesse público, servindo a convicções pessoais.

Demonstrou o exame da prova que o cemitério particular, já interditado por lei estadual, visto distar menos de 18 quilômetros do cemitério público mais próximo, não podia ser desapropriado. Ademais, qual o motivo para abranger no mesmo ato expropriatório o outro imóvel, a não ser por motivo de ordem pessoal? 
O acórdão de 18 de março de 1940 das Câmaras Reunidas do Tribunal de Justiça de Pernambuco, por maioria de votos, em grau de embargos, reformou o Acórdão da $1^{\text {a }}$ Turma da Câmara Cível, julgando procedente a ação anulatória intentada e concluindo pela nulidade do ato administrativo expropriatório, que não se fundamentara no interesse público ("Não é interesse público pretender um prefeito local, violando a Constituição, que assegura a liberdade de culto e proíbe subvenções a qualquer seita religiosa por parte dos poderes públicos, prestigiar os católicos contra os protestantes". Ver Revista dos Tribunais, vol. 129, p. 704).

O mesmo Tribunal de Justiça de Pernambuco, em Acórdão unânime de 22 de fevereiro de 1949, acolhe por inteiro a teoria do desvio de poder e invalida o resultado do procedimento administrativo ao confirmar sentença de primeira instância, anulando ato de Interventor Federal que demitira funcionário público do Estado não para atender a interesses públicos, materialmente incomprovados no caso, mas para atender a móveis de vingança pessoal (julgamento da Apelação n ${ }^{\circ} 34.526$, em Revista de Direito Administrativo, vol. IX, p. 173).

Caso interessante de desvio de finalidade teve ocasião de julgar o Tribunal de Justiça do Rio Grande do Norte. Duas empresas de ônibus concorriam ao transporte de passageiros entre a Capital e a Cidade de São José de Mipibu.

Tendo a repartição de trânsito fixado horário para um delas, esta, o considerando nocivo ao seu interesse e favorável à concorrente, impetrou mandado de segurança.

O Tribunal, reformando sentença de primeiro grau, concedeu o mandado porque, embora àquela repartição competisse, como atribuição necessariamente discricionária, a fixação de horários aos transportes coletivos, segundo o Código de Trânsito, artigos, 56, $\S 2^{\circ}$ e $57, c$, a competência ser exercera com o fim de favorecer uma empresa prejudicando outra, quando a sua outorga só ocorreria por motivos de interesse público (segurança de trajeto, comodidade do público etc. Acórdão de 28 de julho de 1949, em Revista Forense, vol. CXXI, ps. 209-219, e Revista de Direito Administrativo, vol. XIV, p. 52. Ver: Seabra Fagundes, $O$ controle dos atos administrativos pelo Poder Judiciário, $3^{\mathrm{a}}$ ed., 1957, p. 92, nota 5).

Caso típico de desvio de poder foi apreciado pelo Tribunal de Alçada de São Paulo (Ap. Cível no 42.017, em Revista de Direito Administrativo, vol. LXX, ps. 172-174, ano de 1962) quando, a pretexto de que as finanças municipais periclitavam com o excessivo número de servidores, foi demitido funcionário público, nomeado em caráter efetivo.

Caracterizou-se a figura em questão quando, alguns dias depois, dezenas de nomeações foram feitas, sendo que algumas para cargos exatamente da mesma natureza daquele de que fora afastado o servidor demitido.

A finalidade apresentada era o bom andamento do serviço público, mas a finalidade real era outra: a de proporcionar oportunidade para a nomeação de outras pessoas ou outra razão qualquer. "O poder de exonerar e de nomear não é dado aos administradores para que satisfaçam a interesses particulares ou a simpatias ideológicas ou partidárias. Devem visar ao interesse público. E se não existe interesse público algum em que se exonere determinado funcionário (porque a finalidade visada com a exoneração não corresponde àquele interesse) para que se nomeie outro, a exoneração não se legitima. Ocorre, em tal caso, inegável desvio de poder; porque 
o interesse pessoal que inspira o ato não é o fim visado pela lei" (Revista de Direito Administrativo, vol. LXX, p. 173).

"Na espécie, demitido o autor por força de ato que teria como finalidade a economia dos cofres públicos, outras pessoas foram nomeadas para cargos idênticos. Houve, pois, desvio de poder. $\mathrm{O}$ ato demissionário, assim, por mais esse fundamento, deve ser considerado nulo, impondo-se, como consequiência, a procedência da ação" (Revista de Direito Administrativo, vol. LXX, p. 174).

Como se depreende dos arestos selecionados, motivos de natureza religiosa, de vingança ou de favorecimento pessoal caracterizam, em nosso direito, o desvio de poder, dando origem à anulação do ato administrativo inquinado desse vício.

$\mathrm{O}$ exame dos casos apreciados pelos tribunais deixa evidentes as áreas administrativas em que mais frequientemente incide o "desvio de poder".

Em primeiro lugar, o campo reservado ao poder de polícia é o que fornece mais exemplos do desvio de finalidade. Assim, foi na França, na Itália, Espanha e Portugal, o mesmo ocorrendo no Brasil.

Dentro do campo do poder de polícia, o instituto da desapropriação formece muitos exemplos, o mesmo se verificando com o tráfego de veículos.

Em segundo lugar, no terreno do funcionalismo público ocorrem exemplos de desvio de poder, principalmente em casos de puniçôes leves, médias e graves, que culminam no afastamento. Fora desses casos é mais raro o aparecimento do desvio que surge, uma vez ou outra, no campo das licitações.

Como se depreende dos exemplos citados, em nossa jurisprudência já se nota progressiva tendência para exame dos motivos do ato pelo Poder Judiciário (Brandão Cavalcanti, Suplemento - atualizado do Tratado - vol. V, 1964, p. 30). É preciso, entretanto, extrema cautela no desenvolvimento da doutrina, para que o Judiciário não se substitua à Administração, na apreciação da conveniência, especialmente na conveniência técnica e na escolha dos critérios administrativos. 